\title{
Analisis Kesulitan Guru Matematika dalam Menerapkan Proses Pembelajaran Jarak Jauh (Distance Learning)
}

\author{
Perry Zakaria ${ }^{1}$, Abas Kaluku² ${ }^{2}$ Ferdy Rontos ${ }^{3^{*}}$
}

\author{
1,2,3 Jurusan Matematika, Fakultas MIPA, Universitas Negeri Gorontalo, \\ Jl. Prof. Dr. Ing. B. J. Habibie, Tilongkabila, Kabupaten Bone Bolango, Gorontalo 96119, Indonesia
}

\begin{tabular}{|c|c|}
\hline INFO ARTIKEL & ABSTRAK \\
\hline $\begin{array}{l}\text { *Penulis Korespondensi. } \\
\text { Email: } \\
\text { ferdy2178@gmail.com } \\
\text { Diterima: } \\
\text { 18 Februari } 2021 \\
\text { Disetujui: } \\
23 \text { Maret } 2021 \\
\text { Online } \\
\text { 31 Maret } 2021 \\
\text { Format Sitasi: } \\
\text { P. Zakaria, A. Kaluku, } \\
\text { and F. Rontos, "Analisis } \\
\text { Kesulitan Guru } \\
\text { Matematika dalam } \\
\text { Menerapkan Proses } \\
\text { Pembelajaran Jarak Jauh } \\
\text { (Distance Learning)," } \\
\text { Jambura J. Math. Educ., } \\
\text { vol. 2, no. 1, pp.1-14, } 2021 \\
\\
\text { Lisensi: } \\
\text { JMathEdu is licensed } \\
\text { under a Creative } \\
\text { Commons Attribution- } \\
\text { NonCommercial 4.0 } \\
\text { International License } \\
\text { Copyright @ 2021 } \\
\text { Jambura Journal of } \\
\text { Mathematics Education }\end{array}$ & 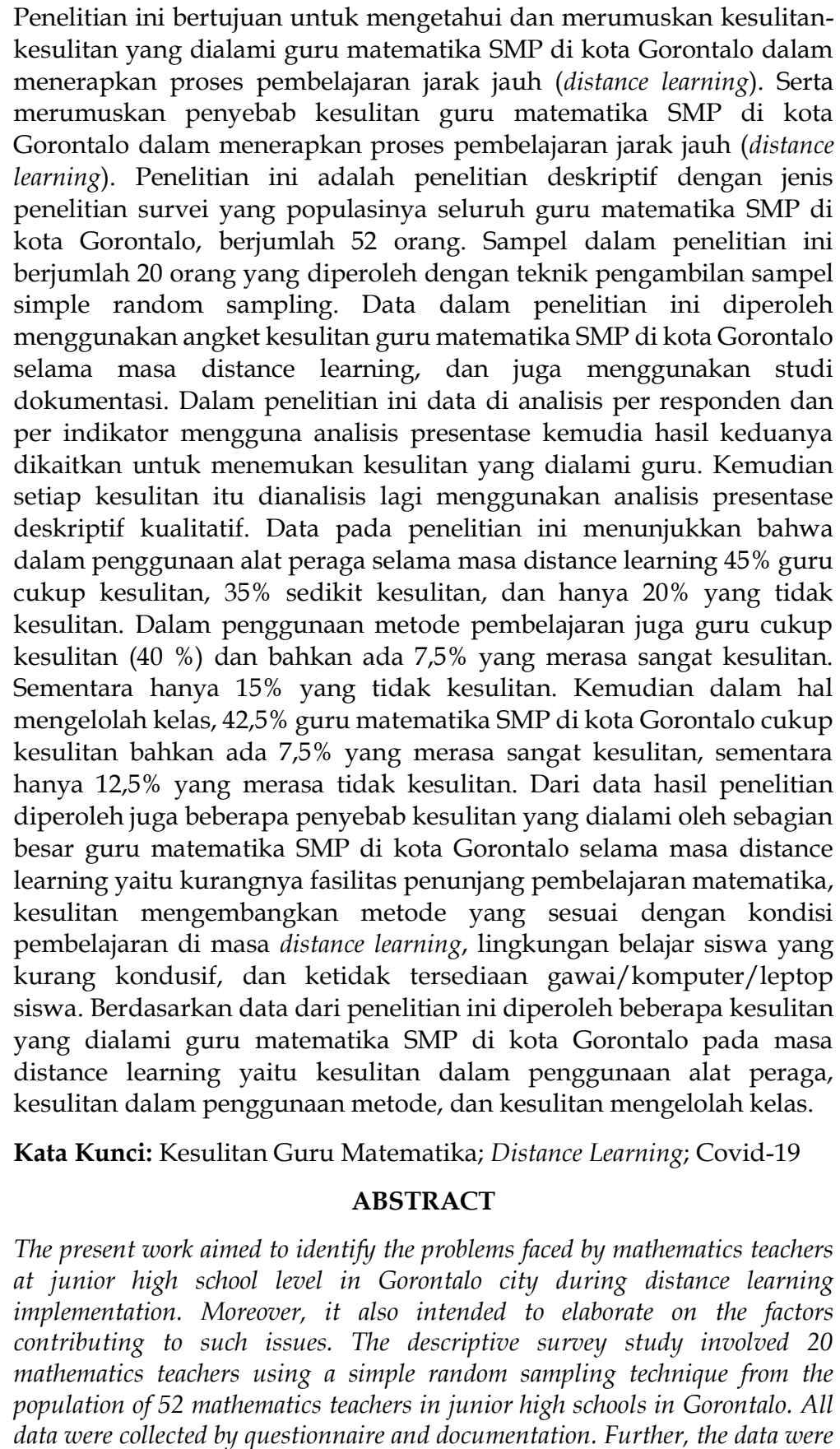 \\
\hline
\end{tabular}


P. Zakaria, dkk | Analisis Kesulitan Guru Matematika dalam Menerapkan Proses ...

analyzed per each respondent and per indicator by percentage analysis; the
analysis results were scrutinized to elaborate on the teacher's problems. Each of
the problems identified was analyzed by percentage analysis and qualitative
descriptive approach. The results indicated that: 1) in terms of incorporating
learning props, $45 \%$ of the respondents considered it hard to apply distance
learning, while 35\% of the teachers found it slightly hard to apply such an
approach. In the meantime, 20\% of the teachers did not find any difficulties. 2)
Regarding the learning method, $40 \%$ of the teachers were quite hard to apply the
distance learning method. Even worse, 7.5\% of the teachers found it very hard
to apply the new learning method. Only 15\% of the respondents did not face any
problems in incorporating the new method. 3) In terms of class management,
42.5\% of the teachers were quite hard to adapt to the new method, and $7.5 \%$
found it very hard in adapting to such a new situation-only $12.5 \%$ of the
teachers who did not face any difficulties at all. Further, the results also indicated
that factors contributing to such problems are: 1) lack of supporting facilities in
the learning process, 2) difficulty in exploring appropriate methods by the
distance learning approach, 3) less-conducive learning environment, and 4$)$
inadequacy of learning gadgets, such as PClaptop. The study concludes that the
mathematics teachers faced problems in three aspects: 1) incorporation of
learning props, 2) implementation of a method, 3) class management.

Keywords: Mathematics teachers' problems; distance learning; COVID-19

\section{Pendahuluan}

Adanya COVID-19 cukup merubah kebiasaan masyarakat dan sistem di berbagai bidang. Salah satunya proses pelaksanaan belajar mengajar. Kebiasaan itu terjadi untuk mencegah penularan virus, diantaranya harus menjaga jarak, mengurangi aktifitas diluar rumah, membiasakan pola hidup sehat serta menjaga kebersihan dan sebagainya. Dunia pendidikan Indonesia juga mengambil bagian dalam upaya pencegahan tersebut. Langkah pencegahan darurat COVID-19 dilakukan kementrian pendidikan dan kebudayaan dengan mengeluarkan beberapa surat edaran. Diantaranya surat edaran Kemendikbud nomor 3 Tahun 2020 Tentang langkah pencegahan COVID-19 pada satuan pendidikan, surat edaran Kemendikbud nomor 4 Tahun 2020 Tentang pelaksanaan kebijakan pendidikan dalam masa darurat penyebaran COVID-19, surat edaran Mendikbud Nomor 15 Tahun 2020 tentang pedoman penyelenggaraan belajar dari rumah dalam masa darurat penyebaran COVID-19. Selain itu Gorontalo yang merupakan salah satu Provinsi di Indonesia yang terdampak COVID-19 juga mengambil bagian dalam pencegahan virus ini khususnya di bidang pendidikan dengan mengeluarkan beberapa surat edaran. Salah satunya surat edaran dinas pendidikan pemerintah kota Gorontalo Nomor: 800/Disdik-Sekrt/3325 tentang panduan pelaksanaan kegiatan belajar mengajar pada satuan pendidikan PAUD, PNF dan pendidikan dasar pada masa tatanan kehidupan normal baru tahun pelajaran 2020/2021 kota Gorontalo. Berdasarkan surat edaran Mendikbud No 15 tahun 2020 dan surat edaran Dinas pendidikan pemerintah kota Gorontalo Nomor: 800/Disdik-Sekrt/3325 khususnya poin 3, pembelajaran dilakuan dari rumah secara daring dan luring [1]. Ini berarti setiap guru dituntut untuk mengajar dari rumah melalui pembelajaran jarak jauh (distance learning).

Tentunya untuk mengoptimalkan proses pembelajaran ini pemerintah, guru, siswa beserta orang tua harus bekerja sama mengupayakan yang terbaik. Dalam menerapkan pembelajaran dari rumah tentunya punya tantangan dan kesulitan tersendiri. Selain faktor ekonomi, lingkungan belajar, fasilitas belajar dan faktor-faktor lain, tidak dapat dipungkiri peran guru dalam menerapkan pembelajaran dari rumah sangat penting sehingga siswa merasa tertolong dan tidak kesulitan memahami pelajaran khusunya 
pelajaran matematika. Dalam situasi ini pemberdayaan guru lebih penting daripada pemberdayaan siswa itu sendiri, karena kualitas siswa itu bergantung juga pada kualitas seorang guru [2] dan pengembangan media yang digunakan pada proses pembelajaran [3]. Sebagai tenaga pengajar dan pendidik seorang guru perlu mengetahui berbagai masalah serta perlu dibimbing untuk menguasai berbagai ketrampilan sehingga ia dapat mengajar secara baik. Namun tidak dapat dipungkiri bahwa guru dalam melaksanakan pembelajaran memiliki tantangan dan mungkin mengalami kendala dan kesulitan. Sehingga guru kurang optimal dan berakibat juga kepada siswa seperti yang sudah disampaikan di atas, apalagi dimasa pendemi seperti sekarang ini. Oleh karena itu, mencari tahu dan merumuskan kesulitan guru dalam menerapkan proses pembelajaran jarak jauh (distance learning) beserta penyebabnya, merupakan salah satu upaya yang dapat dilakukan untuk membantu setiap guru dalam melaksanakan tugasnya. Tentunya dengan merumuskan solusi-solusi yang dapat menjadi jawaban dalam permasalahan ini.

Berbagai penelitian beberapa bulan terakhir terus dilakukan untuk menemukan solusi yang tepat pada pembelajaran Matematika di masa pandemi Covid-19. Annur [4] misalnya, melakukan analisis terhadap kesulitan mahasiswa Pendidikan Matematika pada pembelajaran daring. Kajian terkait pembelajaran secara umum pada masa pandemic Covid-19 juga terdapat pada [5][6]. Selain itu, upaya lain untuk menemukan solusi pembelajaran Matematika dilakukan melalui pendekatan Matematika realistik [7] dan melibatkan pembelajaran dengan video tutorial [8]. Berbagai penelitian yang disebutkan sebelumnya cukup memberikan hasil positif terhadap pembelajaran Matematika, namun belum ditemukan adanya pembahasan khusus yang fokus pada kesulitan yang dialami oleh guru dalam melaksanakan pembelajaran. Padahal sudah menjadi hal yang lumrah, bahwa selain siswa sebagai objek pengajaran, guru sebagai subjek juga banyak mengalami kesulitan selama pelaksanaan pembelajaran jarak jauh di masa pandemi.

Pada makalah ini dilakukan identifikasi kesulitan yang dialami guru matematika SMP di Kota Gorontalo dalam menerapkan proses pembelajaran jarak jauh (distance learning) beserta hal-hal yang menjadi penyebabnya.

\section{Metode}

Penelitian ini bertempat di kota Gorontalo (MGMP Fibonacci Kota Gorontalo) yang dilaksanakan bulan juli sampai desember 2020 dengan subjeknya yaitu 52 orang guru matematika SMP sekota Gorontalo. Responden dalam penelitian ini sebanyak 20 orang Guru matematika SMP di Kota Gorontalo. Peneliti ini merupakan penelitian survei tanpa perlakuan, hanya mengumpulkan data menggunakan instrumen yang telah dibakukan yaitu angket. Dalam penelitian ini peneliti tidak berusaha untuk mengatur atau menguasai situasi pembelajaran dimasa pandemi Covid-19 ini. Jadi perubahan dalam variabel atau kesulitan yang dialami subjek dalam penelitian ini hasil dari peristiwa yang terjadi dengan sendirinya. Secara umum ini merupakan penelitian deskriptif kualitatif.

Teknik pengumpulan data yang digunakan yaitu angket dan studi dokumentasi. Angket dalam penelitian ini terdiri dari 15 pertanyaan yang lahir dari lima indikator yaitu: (1) Kesulitan yang dialami guru matematika dalam penguasaan materi selama masa pendemi dan ditance learning; (2) Kesulitan yang dialami guru matematika dalam menggunakan alat peraga selama ditance learning; (3) Kesulitan yang dialami guru 
matematika dalam menggunakan metode pembelajaran matematika selama masa ditance learning; (4) Kesulitan yang dialami guru matematika dalam mengelolah kelas selama masa ditance learning; (5) Kesulitan yang dialami guru matematika dalam penguasaan dan penggunaan fasilitas (internet dan teknologi) penunjang distance learning. Sepuluh pertanyaan awal bertujuan untuk mendapatkan respon tentang kesulitan yang dialami guru matematika SMP di kota Gorontalo selama masa distance learning. Pada bagian ini setiap indikator diwakili oleh dua pertanyaan. Serta 5 pertanyaan berikutnya bertujuan untuk mendapatkan respon guru terhadap penyebab kesulitan yang dialaminya selama masa distance learning. Dalam bagian ini setiap indikator diwakili oleh satu pertanyaan. Angket dalam penelitian ini dibagikan dan dapat di akses/isi oleh guru secara online menggunakan google formulir. Bentuk Pilihan respon pada pertanyaan 1-10 yaitu dalam bentuk selang "tidak sulit" sampai "sangat sulit". Kemudian untuk pilihan respon pertanyaan nomor 11-15 merupakan angket tertutup, artinya setiap pilihan respon hanya dibatasi dalam cakupan indikator yang ada. Pada bagian ini disediakan beberapa pilihan yang mungkin merupakan penyebab kesulitan yang dialami selama masa distance learning. Responden dapat memilih lebih dari satu respon/pilihan jawaban yang ada. Untuk menampung kemungkinan-keungkinan pilihan respon yang tidak terduga disediakan pilihan respon "lainnya". Artinya responden dapat menyebutkan/menuliskan penyebab lain yang dialaminnya jika tidak terdapat pada pilihan respon yang disediakan. Pada pertanyaan 1-10 responnya menggunakan jenis skala ordinal. Studi dokumentasi dilakukan mulai dari tahapan validasi angkat, karena setiap pertanyaan dan pernyataan dalam angket lahir dari teori-teori. Khusus dalam penelitian ini studi dokumentasi yang dimaksud yaitu mengumpulkan setiap informasi tambahan yang ditemukan selama penelitian. Setiap hal-hal yang berkaitan dengan permasalahan dalam penelitian yang ditemukan selama proses penelitian dicatat sebagai data pendukung.

Teknik pengolahan data yang digunakan dalam penelitian ini yaitu editing dan koding. Dalam penelitian ini sangat sedikit dilakukan proses editing karena setiap respon yang dipilih sudah di validasi terlebih dahulu dan telah mimiliki deskriptornya. Jadi setiap respon yang di pilih sudah sangat jelas, sesuai dengan pertanyaan atau relevan dengan pertanyaan. Sedikit dilakukan proses editing di setiap respon "lainnya" pada pertanyaan 11-15. Pada proses ini setiap respon kesulitan baru yang di sampaikan responden akan di kelompokan dan sesuiakan dengan pertanyaan dan indikator yang ada. Koding yaitu proses untuk mengklasifikasikan jawaban-jawaban para responden menurut kriteria atau macam yang ditetapkan. Klasifikasi itu dilakukan dengan jalan menandai masing-masing jawaban itu dengan tanda kode tertentu. Dalam proses koding pada penelitian ini setiap pertanyaan, respon dan responden diberi kode tertentu untuk untuk memudahkan dalam pengolahan data lanjutan. Angka-angka yang ada bukan merupakan skor namun suatu kode yang mewakili pernyataan atau pertanyaan tertentu. Pada bagian pembahasan nanti setiap kode akan digantikan dengan arti yang sesungguhnya.

Data angket dalam penelitian ini dianalisis menggunakan analisis presentase sedangkan data studi dokumentasi sebagai data temuan di lapangan sebagai data pendukung [8]. Analisis data adalah proses mencari dan menyusun secara sistematis data yang diperoleh dari hasil wawancara, pengamatan, catatan lapangan, dan studi dokumentasi dengan mengotanisasikan data ke sintesis, menyusun ke dalam pola, memilih mana yang penting dan mana yang akan dipelajari, dan membuat kesimpulan sehingga mudah dipahami oleh diri sendiri maupun orang lain. Data dalam penelitian ini di 
analisis per responden dan per indikator menggunakan analisis presentase. Kemudian hasil analisis keduanya di kaitkan untuk mendapatkan indikator yang akan dinyatakan sebagai kesulitan yang ditemukan dalam penelitian ini dan juga untuk mengeliminasi indikator yang tidak termasuk dalam kesulitan yang ditemukan dalam penelitian ini. Setelah itu indikator yang dinyatakan sebagai kesulitan yang ditemukan dianalisis secara presentase setiap jawaban responden (presentase tidak sulit, sedikit sulit, cukup sulit, dan sangat sulit di masing-masing indikator). Secara umum ini menggunakan analisis deskriptif kualitatif.

Adapun teknik analisis data dalam penelitian ini dilakukan dalam tiga tahapan yaitu reduksi data, penyajian data dan penarikan kesimpulan. Reduksi data diartikan sebagai proses pemilihan, pemusatan perhatian pada penyederhanaan data, pengabstraksian dan transformasi data kasar yang muncul dari wawancara [9]. Reduksi data merupakan suatu bentuk analisis yang menajamkan, menggolongkan, mengarahkan, membuang yang tidak perlu dan mengorganisasi data dengan cara sedemikian rupa sehingga kesimpulan dapat ditarik dan diverivikasi. Setelah mengklasifikasikan data atas dasar topik kemudian melakukan abstraksi data kasar tersebut menjadi uraian singkat. Pada tahap ini setiap respon yang ada (data mentah) difokuskan ke bentuk tabel yang memuat jumlah respon tingkat kesulitan di setiap pertanyaan kemudian dipersempit lagi dalam tabel yang memuat jumlah respon tingkat kesulitan pada setiap indikator yang ada. Selanjutnya setiap data yang telah dikhususkan tadi dibuat dalam bentuk presentase untuk memudahkan dalam membaca dan menganalisis data. Data hasil angket dianalisis per indikator dan per responden, kemudian hasil kedua analisis tersebut dikaitkan untuk menemukan kesulitan yang dialami guru. Data yang dianalisis per indikator memperhatikan ketentuan berikut: (1) jika pada pertanyaan yang mewakili indikator lebih banyak jawaban tidak sulit atau sedikit sulit maka indikator tersebut cenderung tidak sulit (cenderung mudah), (2) jika pada pertanyaan yang mewakili indikator lebih banyak jawaban cukup sulit atau sangat sulit maka indikator tersebut cenderung sulit. Untuk mencari persentase tingkat kesulitan pada setiap indikator digunakan rumus sebagai berikut:

$$
\frac{\mathrm{r}_{\mathrm{n}} \mathrm{I}_{\mathrm{k}}}{40} \times 100 \%
$$

dengan: $\quad \mathrm{r}_{\mathrm{n}} \mathrm{I}_{\mathrm{k}}=$ jumlah respon $\mathrm{rn}$ pada setiap indikator $k(I k)$

$$
\begin{array}{ll}
40 & =\text { jumlah total respon } \\
n & =(1,2,3,4) \\
k & =(1,2,3,4,5)
\end{array}
$$

Dalam menganalisis data per responden memperhatikan ketentuan berikut. (1) jika responden lebih banyak memilih pilihan tidak sulit dan sedikit sulit maka responden tersebut cenderung tidak sulit (cenderung mudah) selama masa distance learning. (2) jika responden lebih banyak memilih pilihan cukup sulit dan sangat sulit maka responden tersebut cenderung sulit selama masa distance learning. Setelah ditemukan jumlah responden yang cenderung sulit kemudian diubah kedalam bentuk presentase dengan formula sebagai berikut:

jumlah responden yang cenderung sulit

jumlah seluruh responden

Sementara untuk mendapatkan presentase setiap penyebab kesulitan dicari dengan: 
P. Zakaria, dkk | Analisis Kesulitan Guru Matematika dalam Menerapkan Proses ...

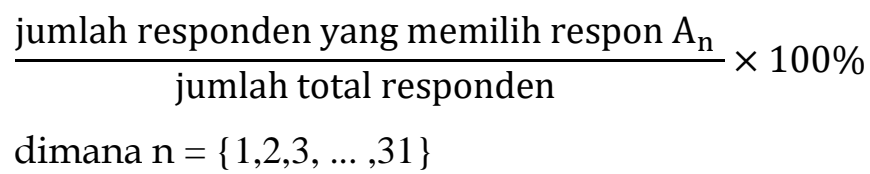

Sementara pada tahap penyajian data setiap data presentase dalam tabel khusus yang telah di buat pada tahap reduksi data, disajikan dalam bentuk diagram lingkaran kemudian dideskripsikan sesuai informasi dalam diagram [4]. Dalam penyajian data, peneliti harus mampu menyusun secara sistematis atau simultan sehingga data yang diperoleh dapat menjelaskan atau menjawab masalah yang diteliti, untuk itu peneliti harus tidak gegabah dalam mengambil kesimpulan. Saat mendeskripsikan data pada diagram, setiap kode yang digunakan di tahap sebelumnya di kembalikan ke makna awalnya (tidak menggunakan istilah/kode angka/huruf lagi). Hal ini dilakukan agar makna dan gambaran yang sesungguhnya mudah dimengerti dan dipahami. Indikator yang cenderung sulit akan dideskripsikan presentase yang menjawab tidak sulit, sedikit sulit, cukup sulit, dan sangat sulit.

Dalam tahap penarikan kesimpulan, setiap data informasi yang diperoleh dari hasil penelitian ini disimpulkan sesuai dengan tujuan penelitan. Kesimpulan dibuat singkat dan jelas. Dalam kesimpulan ini memuat informasi singkat dan jelas tentang kesulitankesulitan yang dialami guru matematika SMP di kota Gorontalo selama masa distance learning dan penyebabnya. Tahap ini dilakukan pada bagian penutup.

\section{Hasil dan Pembahasan}

\subsection{Hasil}

Dari data hasil analisis pada setiap responden diperoleh 25\% responden cenderung sulit. Kemudian setelah dianalisis dari 25\% tersebut menunjukkan cenderung sulita pada indikator 2, 3, dan 4. Hal ini mendukung hasil analisis pada setiap indikator yang juga menunjukkan ketiga indikator tersebut cenderung sulit. Hasil penelitian yang ditunjukkan oleh instrument angket disajikan dalam beberapa tabel berikut. Dari data inilah dapat kita ketahui dan analisis kesulitan apa saja yang dialami guru selama masa distance learning. Tentunya kesulitan ini hanya terikat pada indikator yang ada. Bagian ini juga akan mengeliminasi indikator mana yang bukan merupakan kesulitan jika data menunjukkan demikian. Berikut data dan interpretasi kesulitan guru matematika SMP di kota Gorontalo selama masa distance learning disajikan pada Tabel 1.

Table 1. Persentase tingkat kesulitan di setiap indikator

\begin{tabular}{|c|c|c|c|c|}
\hline \multirow[b]{2}{*}{ Indikator } & \multicolumn{4}{|c|}{ Respon } \\
\hline & $\begin{array}{l}\text { Tidak } \\
\text { Sulit }\end{array}$ & $\begin{array}{l}\text { Sedikit } \\
\text { Sulit }\end{array}$ & $\begin{array}{l}\text { Cukup } \\
\text { Sulit }\end{array}$ & $\begin{array}{c}\text { Sangat } \\
\text { Sulit }\end{array}$ \\
\hline Menguasai materi/bahan ajar & $47,5 \%$ & $42,5 \%$ & $10 \%$ & $0 \%$ \\
\hline Menggunakan alat peraga & $20 \%$ & $35 \%$ & $45 \%$ & $0 \%$ \\
\hline $\begin{array}{l}\text { Menggunakan metode pembelajaran } \\
\text { matematika }\end{array}$ & $15 \%$ & $37,5 \%$ & $40 \%$ & $7,5 \%$ \\
\hline Mengelolah kelas & $12,5 \%$ & $37,5 \%$ & $42,5 \%$ & $7,5 \%$ \\
\hline $\begin{array}{l}\text { Penguasaan dan penggunaan internet- } \\
\text { teknologi }\end{array}$ & $47,5 \%$ & $40 \%$ & $7,5 \%$ & $5 \%$ \\
\hline
\end{tabular}


Dari Tabel 1 dapat dilihat bahwa penguasaan materi bukan suatu kesulitan yang sangat dirasakan guru matematika SMP dikota Gorontalo. Kebanyakan guru (42,5\%) hanya merasa sedikit kesulitan bahkan 47,70\% guru tidak mengalami kesulitan dalam pernguasaan materi. Hanya $10 \%$ guru yang cukup kesulitan dan $0 \%$ sangat kesulitan dalam penguasaan materi selama masa distance learning. Sementara pada indikator kedua, 45\% guru matemtaika SMP di kota Gorontalo cukup kesulitan dalam menggunakan alat peraga selama masa distance learning. 35\% guru sedikit kesulitan dan hanya $20 \%$ yang tidak kesulitan dalam menggunakan alat peraga selama masa distance learning. Tabel 1 di atas juga menggambarkan bahwa guru mengalami kesulitan dalam menggunakan metode pembelajaran matematika selama masa distance learning. 40\% guru cukup kesulitan, 37,50\% guru sedikit kesulitan, 7,50\% merepon sangat kesulitan, dan hanya 15\% yang merespon tidak kesulitan dalam menggunakan metode pembelajaran matematika selama distance learning. Pada indikator ke empat, data menunjukkan 42,50\% guru cukup kesulitan dalam mengelolah kelas, 7,50\% sangat kesulitan, 37,50\% sedikit kesulitan, dan hanya 12,50\% yang merespon tidak kesulitan dalam mengelolah kelas di masa distance learning. Sementara untuk indikator ke lima yaitu penguasaan dan penggunaan internet dan teknologi, data menunjukkan $40 \%$ guru mengalami sediki kesulitan, sementara itu $47 \%$ guru tidak kesulitan dalam penguasaan dan penggunaan fasilitas penunjang distance learning (internet dan teknologi). Sementara masing-masing hanya dibawah $7,50 \%$ yang merespon cukup sulit dan sangat sulit.

Table 2. Persentase penyebab kesulitan

\begin{tabular}{lc}
\hline \multicolumn{1}{c}{ Penyebab kesulitan } & Persentase (\%) \\
\hline Kurangnya sumber reverensi relevan & $15 \%$ \\
Sulitnya akses materi/sumber materi & $0 \%$ \\
Kurangnya kesempatan untuk persiapan penguasaan materi & $25 \%$ \\
Kondisi tubuh yang kurang sehat & $0 \%$ \\
Tingkat kesulitan materi & $15 \%$ \\
Keterbatasan kemampuan/keterampilan & $20 \%$ \\
Kerumitan alat peraga, media, dan sumber belajar & $20 \%$ \\
$\begin{array}{l}\text { Kekeliruan dalam menentukan alat peraga, media, dan sumber } \\
\text { belajar }\end{array}$ & $5 \%$ \\
$\begin{array}{l}\text { Biaya alat praga, media, dan sumber belajar yang kurang } \\
\text { ekonomis }\end{array}$ & $0 \%$ \\
$\begin{array}{l}\text { Tidak tersedia fasilitas penunjang pembelajaran matematika } \\
\text { Kurangnya fasilitas penunjang pembelajaran matematika } \\
\text { Kesulitan mengembangkan metode yang sesuai dengan kondisi } \\
\text { pembelajaran distance learning }\end{array}$ & $20 \%$ \\
$\begin{array}{l}\text { Sedikitnya pilihan metode pembelajaran matematika yang efektif } \\
\text { dan efisien pada masa distance learning }\end{array}$ & $55 \%$ \\
$\begin{array}{l}\text { Kesulitan dalam menguasai metode pembelajaran yang } \\
\text { ditawarkan di masa distance learning }\end{array}$ & $50 \%$ \\
$\begin{array}{l}\text { Karakteristik siswa yang berbeda } \\
\text { Jumlah siswa yang terlalu banyak }\end{array}$ & $40 \%$ \\
$\begin{array}{l}\text { Lingkungan belajar siswa yang kurang kondusif } \\
\text { Ketersediaan smartphone/komputer/leptop guru yang } \\
\text { kurangmemadai }\end{array}$ & $15 \%$ \\
& $45 \%$ \\
& $15 \%$ \\
& $85 \%$ \\
& $5 \%$ \\
&
\end{tabular}




\begin{tabular}{lc}
\hline \multicolumn{1}{c}{ Penyebab kesulitan } & Persentase (\%) \\
\hline $\begin{array}{l}\text { Ketersediaan smartphone/komputer/leptop siswa yang kurang } \\
\text { memadai }\end{array}$ & $45 \%$ \\
$\begin{array}{l}\text { Ketersediaan internet/jaringan yang kurang memadai } \\
\text { Kualitas smartphone/komputer/leptop yang kurang memadai }\end{array}$ & $35 \%$ \\
$\begin{array}{l}\text { Kualitas jaringan/internet yang kurang memadai } \\
\text { Biaya internet yang kurang memadai }\end{array}$ & $30 \%$ \\
$\begin{array}{l}\text { Ketersediaan sumber belajar teknologi dan internet yang dapat di } \\
\text { akses dan dipahami dengan mudah }\end{array}$ & $10 \%$ \\
$\begin{array}{l}\text { Keterbatasan kemampuan dalam penguasaan dan penggunaan } \\
\text { internet dan teknologi }\end{array}$ & $10 \%$ \\
$\begin{array}{l}\text { Lainnya (Kurangnya motivasi peserta didik utk mengikuti } \\
\text { pembelajaran) }\end{array}$ & $15 \%$ \\
$\begin{array}{l}\text { Lainnya (Mengelola kls di daring sulit) } \\
\text { Lainnya (Pengetahuan dasar siswa yg ternyata masih minim) }\end{array}$ & $5 \%$ \\
$\begin{array}{l}\text { Lainnya (Koneksi jaringan internet pada saat melaksanakan } \\
\text { video conference) }\end{array}$ & $5 \%$ \\
$\begin{array}{l}\text { Lainnya (Kurangnya kesiapan peserta didik dalam menggunakan } \\
\text { alat peraga) }\end{array}$ & $5 \%$ \\
Lainnya (tidak ada, tidak sulit, tidak ada kendala, tidak mengisi) & $10 \%$ \\
\hline
\end{tabular}

Dari tabel 2 di atas terlihat bahwa ada banyak penyebab kesulitan yang dialami guru dimasa distance learning. Beberapa diantaranya yang paling dirasakan yaitu lingkungan belajar siswa yang kurang kondusif (85\%), kurangnya fasilitas penunjang pembelajaran matematika (55\%), kesulitan mengembangkan metode yang sesuai dengan kondisi pembelajaran distance learning (50\%), dan ketersediaan gawai/komputer/leptop siswa yang kurang memadai (45\%).

Untuk data tambahan dari studi dokumentasi yang diperoleh selama penelitian yaitu jumlah sekolah SMP di kota Gorontalo sebanyak 22 sekolah, jumlah guru matematika SMP dikota Gorontalo sebanyak 52 orang, serta guru-guru matematika SMP di kota Gorontalo tergabung dalam MGMP Fibonaci kota Gorontalo.

\subsection{Pembahasan}

\subsubsection{Kesulitan Yang Dialami Guru Matematika SMP di Kota Gorontalo selama Masa Distance Learning}

Dilihat dari peran dan tuntutan sebagai seorang guru, terutama guru matematika, sangat kompleks tugas dan tanggung jawab yang harus di embannya. Apalagi karakteristik matematika yang unik [11]. Matematika ada sebagai hasil dari pemikiran manusia yang berhubungan dengan proses, ide, dan penalaran [12]. Matematika adalah ilmu yang berkaitan dengan logika mengenai bentuk, susunan, besaran, dan konsepkonsep yang saling berhubungan dengan jumlah banyak yang dibagi ke dalam tiga bidang yaitu aljabar, analisis dan geometri. Matematika merupakan pola berpikir, pengorganisasian dan pembuktian logik. Selain tuntutan pembelajaran matematika yang kompleks para guru juga diperhadapkan dengan situasi dan kondisi di masa pandemi Covid-19 ini.

Guru dibatasi oleh situasi dan keadaan dalam melakukan tugas dan tanggung jawabnya. Banyak yang tidak terbiasa dengan proses pembelajaran jarak jauh seperti 
yang diterapkan di masa pandemi Covid-19 saat ini, sehingga perlu waktu untuk penyesuaian. Tidak hanya guru namun siswa juga merasa sangat kesulitan, sehingga guru dituntut lebih lagi dalam perannya untuk membantu dan menjamin agar siswa tetap dapat belajar dengan baik serta meminimalisir kesulitan yang dialami siswa [13]. Hal ini didukung beberapa peran guru yang cukup kompleks dalam pembelajaran yaitu guru sebagai sumber belajar, sebagai fasilitator, sebagai pengelolah, sebagai demonstrator, sebagai pembimbing, sebagai motivator, dan sebagai evaluator [14]. Tidak hanya itu saja, peran guru di abad 21 tidak hanya mampu mengajar dan mengelolah kegiatan kelas dengan efektif, namun juga dituntut untuk mampu membangun hubungan yang efektif dengan siswa dan komunitas sekolah, menggunakan teknologi untuk mendukung peningkatan pengajaran serta melakukan refleksi dan perbaikan praktek secara terus menerus dari dalam. Dari pendapat itu, guru dituntut untuk dapat menguasai dan menggunakan teknologi dalam menjalankan proses pendidikan.

Tentu dalam keterbatasnnya seorang guru mengalami bebagai kendala atau kesulitan selama melaksanakan tugas dan perannya di masa pandemi Covid-19. Kesulitan berasal dari kata sulit yang berarti keadaan yang sulit, sesuatu yang sulit, kesukaran, kesusahan (KBBI). Berdasarkan pengertian itu dapat dipahami bahwa kata kesulitan muncul akibat adanya hambatan atau kendala tertentu dalam mengerjakan sesuatu. Tentunya ada banyak kesulitan yang dialami seorang guru selama masa Distance learning ini. namun dalam penelitian ini dibatasi dalam beberapa indikator yang mungkin menjadi kesulitan yang dialami guru matematika SMP di kota Gorontalo. Indikator ini lahir dari beberapa peran guru yang di uraikan pada [15][16]:

Tabel 3. Dasar Indikator

\begin{tabular}{ll}
\hline \multicolumn{1}{c}{ Peran Guru } & \multicolumn{1}{c}{ Indikator } \\
\hline Sebagai Sumber belajar & Menguasai materi/bahan ajar \\
Sebagai Fasilitator & $\begin{array}{l}\text { Menggunakan alat peraga } \\
\text { Menggunakan metode } \\
\text { Sebagai Demonstrator }\end{array}$ \\
$\begin{array}{l}\text { Sebagai Pengelolah Pembelajaran matematika } \\
\text { Membangun hubungan yang } \\
\text { efektif dengan siswa dan } \\
\text { komunitas sekolah Menggunakan } \\
\text { teknologi untuk mendukung } \\
\text { peningkatan mutu pengajaran }\end{array}$ & $\begin{array}{l}\text { Penguasaan dan penggunaan } \\
\text { internet-teknologi }\end{array}$ \\
\hline
\end{tabular}

Berdasarkan data dan fakta yang diperoleh dari penelitian ini diperoleh beberapa kesulitan yang dialami guru matematika SMP di kota Gorontalo pada masa Distance learning yaitu penggunaan alat peraga, penggunaan metode, dan mengelolah kelas. Sementara penguasaan materi serta penguasaan dan penggunaan internet dan teknologi bukan suatu kesulitan yang sangat berarti karena sekitar $47,5 \%$ guru merespon tidak kesulitan, masing-masing dibawah $42,5 \%$ sedikit kesulitan dan sisanya di bawah $10 \%$ yang merasa cukup sulit dan sangat sulit. 


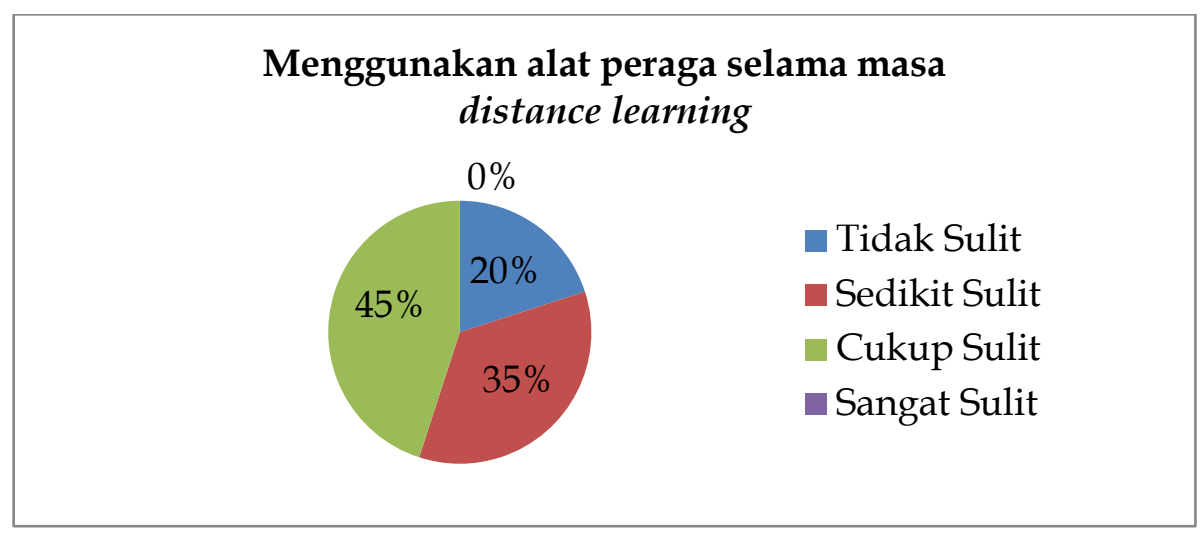

Gambar 1. Persentase tingkat kesulitan dalam penggunaan alat peraga

Dalam penggunaan alat peraga selama masa Distance learning $45 \%$ guru cukup kesulitan, $35 \%$ sedikit kesulitan, dan hanya $20 \%$ yang tidak kesulitan. Data ini menggambarkan bahwa kurang tersediannya fasilitas dan atau alat peraga dan bahan yang diperlukan untuk mengelolah alat peraga serta kondisi dan keterapilan guru yang kurang dapat menguasai dan mengguanakan alat peraga dengan baik. Sebagai fasilitator ada beberapa hal yang harus dipahami guru, khususnya hal-hal yang berhubungan dengan pemanfaatan berbagai media, alat peraga, dan sumber belajar diantaranya yaitu: (a) guru perlu memahami berbagai jenis media, alamt peraga, dan sumber belajar beserta fungsinya masing-masing. (b) guru perlu memiliki keterampilan dalam merancang suatu media. (c) guru dituntut untuk mampu mengorganisasikan berbagai jenis media dan alat peraga serta dapat memanfaatkan berbagai sumber belajar. Pemahaman akan fungsi media sangat diperlukan, belum tentu suatu media cocok digunakan untuk mengajarkan semua bahan pelajaran. Setiap media memiliki karakteristik yang berbeda. Sementara itu, kemampuan untuk merancang media merupakan salah satu kompetensi yang harus dimiliki oleh seorang guru yang profesional. Dengan perencanaan media yang tepat dan dianggap cocok, memudahkan proses pembelajaran sehingga tujuan pembelajaran akan tercapai dengan optimal. Sesuai dengan tuntutan zaman, guru juga seharusnya dapat berkreasi menggunakan kombinasi atau memodifikasi berbagai media dan alat peraga. Nyatanya guru matematika SMP dikota Gorontalo kesulitan dalam memenuhi tuntutan tersebut. Sehingga perlu mendapat perhatian dalam mengatasi kesulitan penggunaan alat peraga yang dialami di masa distance learning serta perlu meningkatkan keterampilan guru SMP di kota Gorontalo terutama dalam hal penggunaan alat peraga. 


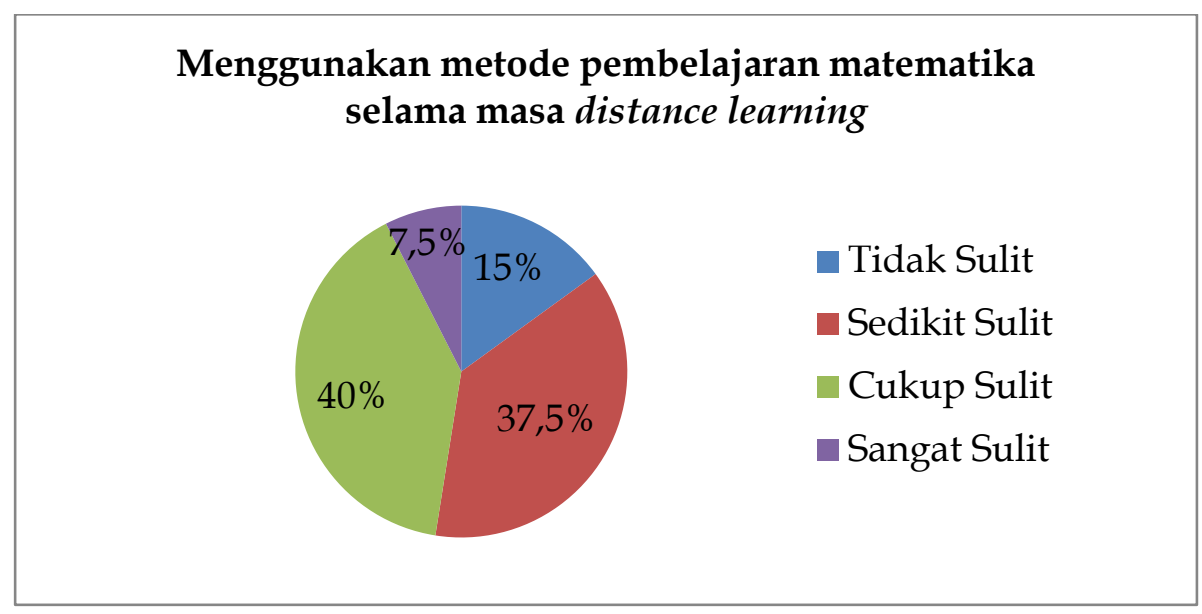

Gambar 2. Persentase tingkat kesulitan dalam penggunaan metode pembelajaran matematika

Dalam penggunaan metode pembelajaran juga guru cukup kesulitan $(40 \%)$ dan bahkan ada $8 \%$ yang merasa sangat kesulitan. Sementara hanya $15 \%$ yang tidak kesulitan dalam penggunaan metode pembelajaran matematika dimasa distance learning. Hal ini menunjukkan bahwa terdapat beberapa pilihan metode pembelajaran matematika namun kurang efektif dan sulit diterapkan di masa distance learning serta kurangnya keterampilan guru dalam mengelolah dan menerapkan metode pembelajaran dengan efektif dan efisien di masa distance learning. Ini mungkin terjadi karena guru hanya terbiasa mengajar dengan kondisi sebelum masa distance learning. Sebagai demonstrator guru harus dapat menunjukkan bagai mana caranya agar setiap materi bisa lebih dipahami dan dihayati oleh stiap siswa. Hal ini berkaitan erat dengan strategi dan metode pembelajaran yang membuat siswa dapat belajar lebih bermakna sesuai dengan tuntutan kurikulum 2013. Namun berdasarkan data yang ada menunjukkan bahwa dalam memenuhi tuntutan ini, guru SMP dikota Gorontalo mengalamin kesulitan dan secara umum belum maksimal dalam melaksanakan tugasnya sebagai demonstrator selama masa distance learning.

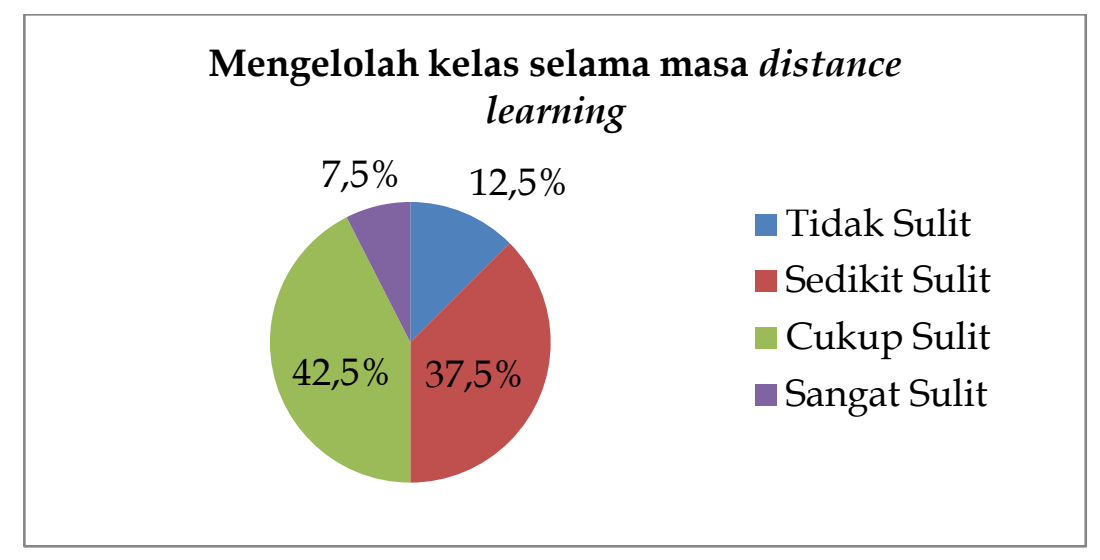

Gambar3. Persentase tingkat kesulitan dalam mengelolah kelas

Dalam hal mengelolah kelas, guru matematika SMP di kota Gorontalo 42,5\% cukup kesulitan bahkan ada 7,5\% yang merasa sangat kesulitan. Sementara hanya 12,5\% yang merasa tidak kesulitan. Data ini menggambarkan keadaan guru yang kurang dapat mengelolah kelas dan menciptakan iklim belajar matematika yang baik dalam kondisi 
distance learning. Sebagai pengelolah pembelajaran (learning maneger) guru berperan dalam menciptakan iklim belajar yang memungkinkan siswa dapat belajar secara nyaman. Melalui pengolahan kelas yang baik guru dapat menjaga kelas agar tetap kondusif untuk terjadinya proses belajar dan tranfer informasi seluruh siswa. Nyatanya ini suatu tugas yang sulit dilakukan dimasa distance learning. Guru sangat terbatas karena pembelajaran dilakukan di tampat yang berbeda atau di tempat yang sama namun kondisi dan situasi yang berbeda. Dalam hal ini tugas mengelolah kelas adalah tugas bersama antar guru dan orang tua.

\subsubsection{Penyebab Kesulitan Yang Dialami Guru Matematika SMP di Kota Gorontalo selama Masa Distance Learning}

Setiap kesulitan yang dialami guru tentu memiliki penyebab tertentu atau bahkan lebih dari satu penyebab. Faktor penyebab kesulitan guru secara umum dapat dibagi menjadi dua yakni faktor internal dan faktor eksternal. Dalam sudut pandang lain faktor-faktor yang menyebabkan kesulitan yaitu faktor fisiologis, faktor sosial, faktor emosional, dan faktor intelektuan. Berdasarkan uraian kedua uraian tersebut maka dapat dikatakan bahwa dalam melaksanakan tugas dan perannya guru dapat dipengaruhi oleh beberapa faktor diantarannya, faktor internal dan faktor eksternal. Faktor internal berkaitan dengan keadaan dari dalam pribadi guru tersebut, seperti motivasi mengajar, kondisi tubuh (fisik, emosional dan psikologis), dan kemampuan yang dimiliki guru. Sedangkan faktor eksternal berkaitan dengan keadaan diluar diri seorang guru seperti lingkungan dan aktifitas sosial serta keadaan di dalam kodisi tertentu. Dalam penelitian ini faktor utama penyebab kesulitan guru matematika SMP di kota Gorontalo adalah pandemi COVID 19 dan kondisi distance learning. Sedangkan di setiap indikator memiliki penyebab kusus.

Distance learning merupakan proses pembelajaran yang dibatasi oleh beberapa situasi, kondisi, dan letak/jarak. Namun tetap mengupayakan terjadinya proses pembelajaran yang optimal. Dikaitkan dengan distance learning di masa pendemi Covid-19 ini, pembelajaran dibatasi oleh situasi dan keadaan yang mengharuskan setiap orang untuk menjaga jarak dan menghindari kontak fisik termasuk aktifitas-aktifitas yang mengumpulkan beberapa orang atau kelompok orang dalam suatu tempat secara bersamaan, termasuk aktifitas pembelajaran di sekolah. Dalam situasi ini pembelajaran dilakukan jarak jauh meski terdapat beberapa yang harus bertemu secara terbatas dalam pembelajaran dengan menerapkan protokol kesehatan di masa pandemi Covid-19 dengan ketat. Siswa belajar dari tempat tinggal masing-masing serta guru melaksanakan perannya dari tempat kediamannya tanpa berkumpul dalam ruang kelas tertentu secara bersamaan. Siswa, guru, dan orang tua dutuntut untuk sama-sama bersinergi dalam mendukung tercapainya tujuan pembelajaran yang diharapkan.

Dari data hasil penelitian diperoleh beberapa penyebab kesulitan yang umumnya dialami oleh sebagian besar guru matematika SMP di kota Gorontalo selama masa Distance learning yaitu lingkungan belajar siswa yang kurang kondusif, kesulitan mengembangkan metode yang sesuai dengan kondisi pembelajaran di masa Distance learning, kurangnya fasilitas penunjang pembelajaran matematika, dan ketidak tersediaan gawai/komputer/leptop siswa.

Sebagai fasilitator ada beberapa hal yang harus dipahami guru, khususnya hal-hal yang berhubungan dengan pemanfaatan berbagai media, alat peraga, dan sumber belajar diantaranya yaitu: (a) guru perlu memahami berbagai jenis media, alamt peraga, dan 
sumber belajar beserta fungsinya masing-masing. (b) guru perlu memiliki keterampilan dalam merancang suatu media. (c) guru dituntut untuk mampu mengorganisasikan berbagai jenis media dan alat peraga serta dapat memanfaatkan berbagai sumber belajar. Namun dalam kaitannya dengan tugas tersebut guru matematika SMP di kota Gorontalo mengalami kesulitan yang disebabkan oleh kurangnya fasilitas penunjang pembelajaran matematika. Sebagai demonstrator guru harus dapat menunjukkan bagai mana caranya agar setiap materi bisa lebih dipahami dan dihayati oleh stiap siswa. Hal ini berkaitan erat dengan strategi dan metode pembelajaran yang membuat siswa dapat belajar lebih bermakna sesuai dengan tuntutan kurikulum 2013. Namun dalam kaitannya dengan tugas tersebut guru matematika SMP di kota Gorontalo mengalami kesulitan yang disebabkan oleh mengembangkan metode yang sesuai dengan kondisi pembelajaran di masa distance learning. Sebagai pengelolah pembelajaran (learning maneger) guru berperan dalam menciptakan iklim belajar yang memungkinkan siswa dapat belajar secara nyaman namun dalam kaitannya dengan tugas tersebut guru matematika SMP di kota Gorontalo mengalami kesulitan yang disebabkan oleh lingkungan belajar siswa yang kurang kondusif.

Salah satu penyebab kesulitan yang paling dirasakan guru matematika SMP di kota Gorontalo selama masa distance learning adalah ketidak tersediaan gawai/komputer/leptop siswa. Penyebab ini sangat erat kaitannya dengan kondisi distance learning yang menuntut pembelajaran dalam jaringan. Tentunya membutuhkan teknologi seperti alat kominikasi gawai atau leptop/komputer untuk mendukung berlangsungnya pembelajaran dalam jaringan. Jika ini kurang terpenuhi akan mempersulit tugas guru dalam melaksanakan pembelajaran di masa distance learning.

Setiap kesulitan yang dialami guru matematika SMP di kota Gorontalo selama masa distance learning mungkin saja mendapatkan solusi melalui forum MGMP Fibonaci yang menaungi setiap guru matematika SMP di kota Gorontalo. Setiap guru mengalami kesulitan yang cukup bervariasi sehingga forum MGMP dapat menjadi wadah tempat mendiskusikan setiap kesulitan dan kendala yang dihadapi beserta solusinya. Dengan begitu akan ditemukan beberapa solusi yang mungkin dapat diterapkan bersama terutama terkait permasalahan kesulitan guru yang telah dibahas diatas.

\section{Kesimpulan}

Beberapa hal yang menjadi kesulitan guru matematika SMP di kota Gorontalo selama masa Distance Learning yaitu: (1) Kesulitan menggunakan alat peraga, pernyataan ini menggambarkan bahwa kurang tersediannya fasilitas dan atau alat peraga dan bahan yang diperlukan untuk mengelolah alat peraga serta kondisi dan keterapilan guru yang kurang dapat menguasai dan mengguanakan alat peraga dengan baik. (2) Kesulitan menggunakan metode pembelajaran matematika, hal ini menunjukkan bahwa terdapat beberapa pilihan metode pembelajaran matematika namun kurang efektif dan sulit diterapkan di masa distance learning serta kurangnya keterampilan guru dalam mengelolah dan menerapkan metode pembelajaran dengan efektif dan efisien di masa distance learning. (3) Kesulitan dalam mengelolah kelas, pernyataan ini menggambarkan keterampilan guru yang kurang dapat mengelolah kelas dan menciptakan iklim belajar matematika yang baik dalam kondisi distance learning. Setiap kesulitan yang dialami guru matematika SMP di kota Gorontalo selama masa distance learning di atas disebabkan oleh kurangnya fasilitas penunjang pembelajaran matematika, kesulitan mengembangkan metode yang sesuai dengan kondisi pembelajaran di masa distance 
P. Zakaria, dkk | Analisis Kesulitan Guru Matematika dalam Menerapkan Proses ...

learning, dan lingkungan belajar siswa yang kurang kondusif. Selain itu bebeberapa penyebab kesulitan lain yang hanya dirasakan oleh sebagian kecil guru.

\section{Referensi}

[1] "SE-Sesjen-Nomor-15-Tahun-2020-2.pdf." Accessed: Feb. 18, 2021. [Online]. Available:https:// bersamahadapikorona.kemdikbud.go.id/wpcontent/uploads/2020/05/SE-Sesjen-Nomor-15-Tahun-2020-2.pdf.

[2] R. AD, Mengajar Dengan Sukses. Jakarta: Grasindo, 2008.

[3] P. U. Suseno, Y. Ismail, and S. Ismail, "Pengembangan Media Pembelajaran Matematika Video Interaktif berbasis Multimedia," Jambura J. Math. Educ., vol. 1, no. 2, pp. 59-74, Sep. 2020.

[4] M.F. Annur and H. Hermansyah, "Analisis Kesulitan Mahasiswa Pendidikan Matematika dalam Pembelajaran Daring pada Masa Pandemi Covid-19," Paedagoria: Jurnal Kajian Penelitian dan Pengembangan Kependidikan, vol. 11, no. 2, pp. 195-201, 2020.

[5] L. D. Herliandry, N. Nurhasanah, M. E. Suban, and H. Kuswanto, "Pembelajaran Pada Masa Pandemi Covid-19," JTP - J. Teknol. Pendidik., vol. 22, no. 1, pp. 65-70, Apr. 2020.

[6] A. Amalina, "Pembelajaran Matematika Anak Usia Dini di Masa Pandemi COVID19 Tahun 2020," J. Obs. J. Pendidik. Anak Usia Dini, vol. 5, no. 1, p. 538, Jul. 2020.

[7] S. D. Handayani and A. Irawan, "Pembelajaran matematika di masa pandemic covid-19 berdasarkan pendekatan matematika realistik," J. Math Educ. Nusant. Wahana Publ. Karya Tulis Ilm. di Bid. Pendidik. Mat., vol. 6, no. 2, pp. 179-189, Nov. 2020.

[8] H. H. Batubara and D. S. Batubara, "Penggunaan Video Tutorial untuk Mendukung Pembelajaran Daring di Masa Pandemi Virus Corona," Muallimuna J. Madrasah Ibtidaiyah, vol. 5, no. 2, p. 21, May 2020.

[9] I. Iskandar, Metodologi Penelitian Pendidikan dan Sosial (Kuantitatif dan Kualitatif). Jakarta: Gaung Persada Press, 2008.

[10] M.B Matthew and H. A. Michael, Analisis data kualitatif: buku sumber tentang metode metode baru. Jakarta: (UI -Press), 1992.

[11] R. E.T, Pengajaran Matematika Modern. Bandung: Tarsito, 1980.

[12] E. Suherman, Strategi Pembelajaran Matematika Kontemporer. Bandung: JICA-UPI, 2001.

[13] W. Sanjaya, Strategi pembelajaran berorientasi standar proses pendidikan. Jakarta: kencana prenada media, 2019.

[14] D.E. Andriani, "Mengembangkan Profesionalitas Guru Abad 21 Melalui Program Pembimbingan Yang Efektif," J. Manaj. Pendidik. UNY, Oct. 2010.

[15] A.B. Zuhairatul, "Analisis Kesulitan Guru dalam Menerapkan Pendekatan Saintifik di MIN I Lombok Tengah Tahun Pelajaran 2017/2018," Universitas Islam Negeri Mataram, Mataram, 2018.

[16] A. S. Muslimah, "Analisis Kesulitan Guru SMA dalam Pembelajaran Ekonomi Berdasarkan Kurikulum 2013 MGMP di Kabupaten Sleman," Universitas Negeri Yogyakarta, Yogyakarta, 2015. 